ACTA AGROBOTANICA

Vol. 61 (2): 93-101

2008

\title{
SPATIAL ANALYSIS OF PLANT SPECIES DISTRIBUTION AMONG SMALL WATER BODIES IN AN AGRICULTURAL LANDSCAPE
}

\author{
Beata Bosiacka1, Krzysztof Pacewicz ${ }^{2}$, Pawel Pieńkowski ${ }^{3}$ \\ ${ }^{1}$ Department of Plant Taxonomy and Phytogeography, University of Szczecin, Wąska 13, 71-415 Szczecin, Poland; \\ e-mail: bebos@univ.szczecin.pl \\ ${ }^{2}$ Department of Biometry, University of Agriculture, Pawła VI 3, 71-442 Szczecin, Poland \\ ${ }^{3}$ Department of Environmental Protection and Development, University of Agriculture, J. Słowackiego 17, 71-434 Szczecin, Poland
}

Received: 16.01 .2008

S u m m a r y :

Due to their small size (0.02-1.0 ha), distinct boundaries, and conditions highly contrasting with those in the surrounding area, midfield water bodies are regarded as the so-called habitat islands. Their effective conservation calls for knowledge on their inhabitants' dispersal potential. However, direct empirical data are available for very few species only, but dispersal potential of a species may be inferred indirectly, from its distribution. The study addressed the question whether there is spatial autocorrelation in the distribution of plant species in midfield water bodies, or if the distribution is random.

Spatial distribution of the midfield water bodies surveyed was analysed using the CrimeStat software, while spatial autocorrelation in distribution of 29 species was explored with the joincount.test routine of R CRAN software. Explorative spatial data analysis (ESDA) involving join-count statistics showed the presence of positive spatial autocorrelation in the distribution of ten hydro- and helophytic species. In their case, ESDA made it possible to reject the random distribution hypothesis, which opens up an avenue for exploring spatial patterns. Activities promoting the occurrence of species with limited dispersal potential should take into account their preferences in terms of shorter distances between neighbouring sites. This should make it possible to plan conservation of midfield water bodies not only as refuges, but also as stepping stone habitats facilitating migrations of wild species growing in an agricultural landscape.

Key words: midfield water bodies, plant species, distribution, spatial autocorrelation, lattice model, agricultural landscape

\section{INTRODUCTION}

Midfield water bodies are frequently the only open-water biotopes in an agricultural landscape. Due to their small size (0.02-1.0 ha), distinct boundaries, and conditions clearly contrasting with those prevail- ing in the surroundings, midfield water bodies are regarded as the so-called habitat islands ( R a ty ń s ka, 2002; P u 11 in, 2002).

Results of studies on the bio- and physiocoenotic role of midfield ponds have been instrumental for the increasingly frequent activities aimed at preservation of those small water bodies, and even at their restoration (K u charski and Samosiej, 1990; B o othby et al. 1996). Such activities are particularly important in view of the disappearance of small water bodies in north-western and central Europe. In some areas, the intensification of agriculture and drainage operations carried out in the 20th century resulted in the disappearance of as many as $90 \%$ of midfield ponds (Hull, 1997; P i eń k o w s k i, 2003)

Effective conservation of habitat islands, including midfield water bodies, calls for the knowledge on dispersal potential of their inhabitants. However, for very few species are empirical data available. Mobility of higher plants occurs only at the recruitment stage, either through dispersal of seeds or other propagules or clonal growth. Dispersal limitation must be invoked as a major factor determining species distributions over a landscape (Greene and Calogeropoulos, 2002; B ull o ck et al. 2002).

As direct studies on dispersal potential of higher plants are difficult to conduct, that potential can be explored indirectly, by analysing species distributions. For example, when studying presence/absence species patterns among habitats, distance-related weights may serve indirectly as a representative of dispersal probability among habitats, assuming that dispersal probability is inversely related to distance ( $\mathrm{S}$ t e v e $\mathrm{n} \mathrm{s}$ and J e n k i n s, 2000).

This study was aimed at analysis of distribution of selected vascular plant species among midfield wa- 
ter bodies. The study addresses the question whether there is a pattern to the spatial distributions (spatial autocorrelation), or if the distributions are random. In other words, the problem boils down to finding out if the presence of a phenomenon (species) in a spatial unit analysed increases or reduces the probability of the phenomenon (species) occurring in neighbouring, similar units.

\section{MATERIALS AND METHODS}

The study on flora and vegetation of 33 midfield water bodies was conducted in August 2003 (B o s i a $\mathrm{cka}$ and Myśliwy, 2004) over an area of about 6000 ha in the western part of the Słowińskie Coast (northern Poland) (Fig. 1). Cultivated land covers more than $55 \%$ of the area, its central and western part being forested. There are no lakes and rivers, but midfield water bodies are relatively abundant and occur almost exclusively within stretches of cultivated land.

Analysis of spatial distribution of the midfield water bodies was carried out using the CrimeStat software (L e vine, 1999). Nearest neighbour analysis (Earickson and Harlin, 1994) was used to estimate the regularity of distribution. Mean random distance for random distribution in nodes of a quadrant grid was calculated with the formula:

$$
d(\text { ran })=0.5 \sqrt{\frac{A}{N}}
$$

where:

A, surface area

$\mathrm{N}$, number of nodes (sampling sites)

Nearest neighbour distance was calculated

with:

$$
d(N N)=\sum_{i=1}^{N}\left(\frac{d_{i}}{N}\right)
$$

where:

$\mathrm{N}$, number of nodes (sampling sites)

bour

$d_{i}$, distance of $i$ th point from its nearest neighwith:

Nearest neighbour index $N N I$ was calculated

$$
N N I=2 \frac{\sum_{i=1}^{N} d_{i}}{N \sqrt{\left(\frac{A}{N}\right)}}
$$

Statistical analysis of distribution of selected plant species among the midfield water bodies surveyed was based on a set of binary data on the presence or absence of each species in each pond.
The presence/absence pattern for a species may be considered analogous to that of a mixed-up chess board, with $B$ (black) for species present and $W$ (white) for species absent. Statistics based on binary random variables (where present $=1$, absent $=0$ ) can then be calculated to determine whether the patterns of $B$ 's and $W$ 's are random or show some sort of clustering. $\mathrm{C} \mathrm{l}$ if $\mathrm{f}$ and O r d $(1973,1981)$ developed three join-count statistics, designated $B B, B W$, and $W W$. For species presence/absence data, species status $x_{i}$ is either 1 (corresponding to $B=1)$ or $0(W=0) . B B$ join-counts represent the statistics for all pairs of sampling sites where both sites have a value of $B$ (species present), $B W$ join-counts represent the statistic for all pairs of sites where one site is $B$ (species present) and the other is $W$ (species absent). The final join-count, $W W$ represents the statistic for all pairs of sites where both sites are $W$ (species absent). The three statistics are as follows:

$$
\begin{gathered}
B B=\frac{1}{2} \sum_{i=1}^{n} \sum_{j=1}^{n}{ }_{i \neq j} w_{i j} x_{i} x_{j} \\
B W=\frac{1}{2} \sum_{i=1}^{n} \sum_{j=1}^{n}{ }_{i \neq j} w_{i j}\left(x_{i}-x_{j}\right)^{\prime} \\
W W=\frac{1}{2} S_{0}-(B B+B W)
\end{gathered}
$$

where:

$$
S_{0}=\sum_{i=1}^{n} \sum_{j=1}^{n}{ }_{i \neq j} \omega_{i j}
$$

$w_{i j}$ is the weight (Euclidean distance) between site $i$ and site $j$, and $x_{i}$ is the value of the binary random variable at site $i(1=$ present, $0=$ absent $)$.

The statistics $B B$ and $W W$ refer to positive spatial autocorrelation, BW representing negative autocorrelation.

The analysis of spatial autocorrelation was performed with the R CRAN version 2.6.0 software (Program R...2007), using joincount.test routine which is based on the non-free sampling approach. The nonfree sampling (randomisation) approach assumes the number of regions of a given colour to be fixed, assigning a colour to a region being variable only. The null hypothesis tested assumed a random distribution of the species over the number of ponds where the species was present, the correlation coefficient being equal to 0 ; the hypothesis was accepted when p-value $>0.05$. The alternative hypothesis $\left(\mathrm{H}_{1}\right)$ assumed the presence of spatial autocorrelation, the correlation coefficient being $>0$; the alternative hypothesis was accepted when p-value $<0.05$ (K o p c zew s ka, 2006). 


\section{RESULTS}

Assuming midfield ponds to be point objects (sampling sites), a mean distance away from the nearest neighbour was used as a general measure of distance between the ponds. In this study, that value is 445.45 $\mathrm{m}$, the minimum and maximum distances being 83.44 and $6632.25 \mathrm{~m}$, respectively. The scatter of the objects was measured with NNI which, at the theoretical mean distance of $459 \mathrm{~m}$, is 0.97 , indicating the distribution of the ponds to be close to random.

The analyses of species distribution among the midfield water bodies involved only those species indicative of hydrogenic habitats (belonging to the classes Lemnetea, Potametea, and Phragmitetea). Species presence/absence (Tab. 1) was used to calculate joincount statistics. Six species were not included, because they appeared in one pond each and could not be considered as displaying a pattern amenable to statistical analysis.

Explorative spatial data analysis (ESDA) involving join-count statistics showed the presence of spatial autocorrelation in the distribution of ten hydroand helophytic species among the midfield water bodies sampled. Autocorrelation was being sought using 10 radii of length ranging from 250 to $2500 \mathrm{~m}$. All the midfield ponds in the area of study became connected with their neighbours when the radius reached 1500 $\mathrm{m}$. Table 2 summarises p-values of the $B B$ statistics for all the 29 species analysed and for five autocorrelation search radii (1500 to $2500 \mathrm{~m}$ ). For all the five search radii, spatial autocorrelation was detected in the distribution of only two species: Equisetum fluviatile and Hottonia palustris. Most species showed positive autocorrelation in their respective distributions at the search radius of $2250 \mathrm{~m}$; these were: Alisma plantagoaquatica, Carex gracilis, Eleocharis palustris, Equisetum fluviatile, Glyceria maxima, Hottonia palustris, Rumex hydrolapathum, Sparganium erectum and Typha latifolia.

Figure 2 shows all the possible connections between the midfield water bodies at the search radius of $2250 \mathrm{~m}: 17$ ponds show the fewest number of connections (5) with their nearest neighbours, while 4 ponds have the highest number (15) of such connections. The total number of connections between all the ponds, at the search radius of $2250 \mathrm{~m}$, is 344 .

Table 3 presents the complete set of results of the joincount.test routine for statistics $B B$ of all the indicator species at the spatial autocorrelation search radius of $2250 \mathrm{~m}$. As the test compares the observed frequency of connections "between identical colours" with the expected frequency, autocorrelation is assumed to occur when "identically coloured" objects are connected at a frequency higher than expected.
With this assumption in mind, the strongest positive spatial autocorrelation at the search radius of $2250 \mathrm{~m}$ was shown by distributions of Sparganium erectum and Equisetum fluviatile.

\section{DISCUSSION}

The high diversity of plant communities in midfield water bodies is, according to $\mathrm{K}$ a ź $\mathrm{mie} \mathrm{r} \mathrm{c} \mathrm{z} \mathrm{a} \mathrm{k}$ et al. (1995), only partially correlated with the measurable habitat diversity. The presence of different species in habitats that are similar in terms of their abiotic conditions can be explained by random colonisation and availability of diasporas from seed banks or from the nearest sources of dispersal.

Dispersal limitations are important for population dynamics of species inhabiting habitat islands. Such biotopes are particularly strongly isolated in the monotonous agricultural landscape. Population persistence is guaranteed by migrations between habitats, and migrations are facilitated by the distribution of habitat patches that is correlated with a species' dispersal potential. Due to the increasing habitat fragmentation and disappearance of many habitat islands, including midfield water bodies, it becomes necessary to develop methods for conservation of such habitats or for restoration of their physiocoenotic functions (P u 11 i n, 2002).

Methods of spatial statistics belonging to the explorative spatial data analysis (ESDA) group are commonly used in geography and in econometrics; in contrast, examples of their application to ecological studies are few and far between. Join-count statistics represent a type of statistics testing for spatial correlations. They may prove as a tool in biotic inventories and surveys of plant and animal species among habitat islands. If habitat requirements need to be assessed, or if habitats need to be managed, the most scientificallydefensible approach would be to first demonstrate that species is occupying habitats non-randomly ( $\mathrm{Ste}$ vens and Jenkins, 2000).

Statistical analyses of spatial distributions are best performed with larger numbers of sample sites (e.g. >50), but studies of multiple habitat islands, e.g. midfield ponds, can rarely approach these numbers due to practical constraints and the limited numbers of ponds remaining in a human-dominated landscape.

Stevens and Jenkins (2000) analysed spatial patterns of crustacean species among 15 ponds using join-count statistics. They used a permutation test too (for small-scale reliability) and concluded that the same species were distributed non-randomly. In the absence of more information, those authors considered it reasonable to use inter-site distance in the weighting matrix, on the assumption that distance is related to dispersal probabilities among sites. 
m0000000-000000-t-0000-000-000000-0-0 m$\bar{m} 000000-00000000-0000-1-00-000000000-1$ m00000-000000000-0000-0000000000000สิ000000000000000-000000000000000000ה $0-00000000000-00-0-0-00-00-000-00--$ స0000000000000-00-0-0-000-00000000-0 N $0000000000000000-000-1-00-00000-0000$ M0000000-10000000-0000-000000000000-I $0-000000000-00-00000-00-00-0000000-1$ 凡000000000-100000-100-10-1-000-10000-10000 A $000000000000000-000000000000000000-$ $\overline{\mathrm{N}} 000000-00-0000-1-00-0-00-00000000-00$ సิ $000000000000000-0000--1-1000000000-0$ H $=0000-000000-0---0000000-1-0-00-00-0-1$ D $0000-000000000000000-00-00000000-10$ $=0000-0000000000000-0-1000-0000-0000$ L $000000-00000000-0000-10-0-000000000$ $\dot{z}=00000000000000-000-000-0000000-100-1$ I0 - $000000000--1-00000-000-0-00000-00$ m000000000000000-0000-1000000000000-I- $=0-0000-1-0-0-0-1-0-1-000000000-000-00$ $=000000-0000-1-0-0000-100000000000-00$ a $000000-1-0-000--1-1-00-0000-0000-0000$

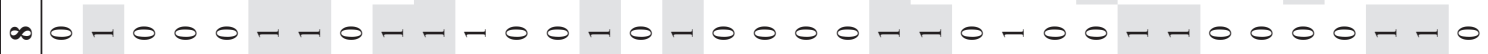
- $-0000-000000-000000-10000-00000-10$ $0000000000-0-000-1000--1000--10000--1$ m00-0-000000-000-0000-1-0000-00000000 $+0-000000000-00-1-0000-000000000000-0$ m00000-00000000-t-00-0-00000000000000 N $000-00-00-0000000000-10-00000000000$ - $-0-0000-1000-100-0000-10-00-0000-0-1$

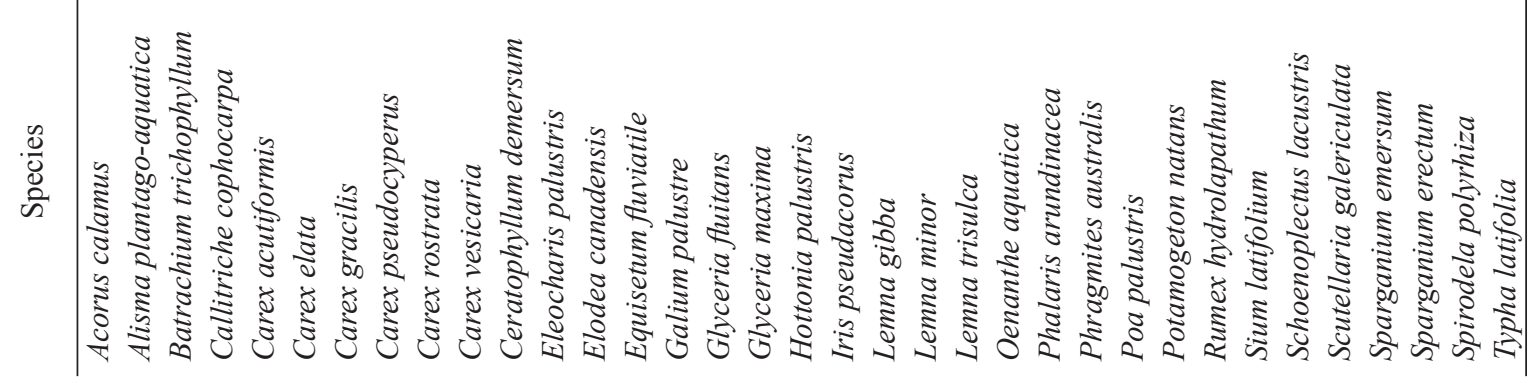


Table 2

Summary of join-count analysis results: $\mathrm{p}$-values for BB statistics; $\mathrm{n}$ - number of ponds in which a species was present; $\mathrm{r}$ - radius of spatial autocorrelations search; asterisks denot p-values considered significant $(<0.05)$ for this study.

\begin{tabular}{|c|c|c|c|c|c|c|}
\hline \multirow{2}{*}{ Species } & \multirow{2}{*}{$\mathrm{n}$} & \multicolumn{5}{|c|}{$\mathrm{r}[\mathrm{m}]$} \\
\hline & & 1500 & 1750 & 2000 & 2250 & 2500 \\
\hline Acorus calamus & 2 & 0.6650 & 0.6980 & 0.7280 & 0.7490 & 0.7660 \\
\hline Alisma plantago-aquatica & 9 & 0.1590 & 0.0660 & 0.0730 & $0.0400^{*}$ & 0.0710 \\
\hline Carex acutiformis & 5 & $0.0200 *$ & $0.0460 *$ & 0.2950 & 0.2700 & 0.1040 \\
\hline Carex elata & 5 & 0.3530 & 0.3810 & 0.1290 & 0.0910 & 0.1430 \\
\hline Carex gracilis & 10 & 0.4630 & 0.3870 & 0.3970 & $0.0490^{*}$ & 0.1380 \\
\hline Carex pseudocyperus & 5 & 0.8310 & 0.6620 & 0.8110 & 0.6650 & 0.7260 \\
\hline Carex vesicaria & 7 & 0.1100 & 0.0760 & 0.1720 & 0.0750 & 0.1410 \\
\hline Eleocharis palustris & 9 & 0.1240 & 0.0830 & $0.0490^{*}$ & $0.0540^{*}$ & $0.0310^{*}$ \\
\hline Elodea canadensis & 3 & 0.3890 & 0.4370 & 0.4260 & 0.1250 & 0.1250 \\
\hline Equisetum fluviatile & 10 & $0.0330^{*}$ & $0.0012^{*}$ & $0.0029 *$ & $0.0239 *$ & $0.0597 *$ \\
\hline Galium palustre & 10 & 0.0850 & 0.9648 & 0.5020 & 0.4430 & 0.6640 \\
\hline Glyceria fluitans & 24 & 0.3750 & 0.2888 & 0.5870 & 0.8530 & 0.8620 \\
\hline Glyceria maxima & 6 & $0.0370^{*}$ & $0.0370^{*}$ & $0.0420^{*}$ & $0.0480 *$ & 0.1270 \\
\hline Hottonia palustris & 3 & $0.0162 *$ & $0.0097 *$ & $0.0110^{*}$ & $0.0265^{*}$ & $0.0350 *$ \\
\hline Iris pseudacorus & 8 & 0.8340 & 0.9030 & 0.9250 & 0.9270 & 0.8230 \\
\hline Lemna minor & 27 & 0.9310 & 0.9410 & 0.7960 & 0.6220 & 0.7930 \\
\hline Lemna trisulca & 13 & 0.4820 & 0.6460 & 0.6410 & 0.6220 & 0.6870 \\
\hline Lotus uliginosus & 4 & 0.3570 & 0.3940 & 0.5140 & 0.5760 & 0.0640 \\
\hline Oenanthe aquatica & 3 & 0.7750 & 0.8220 & 0.8600 & 0.8840 & 0.9020 \\
\hline Phalaris arundinacea & 13 & 0.9100 & 0.6250 & 0.4220 & 0.3480 & 0.4080 \\
\hline Phragmites australis & 6 & 0.5810 & 0.1580 & 0.1480 & 0.0740 & 0.1110 \\
\hline Poa palustris & 5 & 0.0660 & 0.2710 & 0.4110 & 0.6550 & 0.7710 \\
\hline Potamogeton natans & 9 & 0.5360 & 0.3560 & 0.3550 & 0.4540 & 0.4320 \\
\hline Rumex hydrolapathum & 3 & 0.1000 & 0.0860 & $0.0089^{*}$ & $0.0220 *$ & $0.0350 *$ \\
\hline Sium latifolium & 2 & 0.6650 & 0.1710 & 0.1710 & 0.1780 & 0.1750 \\
\hline Scutellaria galericulata & 5 & 0.7990 & 0.8670 & 0.7510 & 0.7930 & 0.6700 \\
\hline Sparganium emersum & 3 & 0.7750 & 0.3040 & 0.3950 & 0.5110 & 0.5680 \\
\hline Sparganium erectum & 8 & 0.1150 & $0.0050^{*}$ & $0.0420^{*}$ & $0.0190 *$ & $0.0460^{*}$ \\
\hline Spirodela polyrhiza & 12 & 0.8920 & 0.8960 & 0.7900 & 0.7460 & 0.8680 \\
\hline Typha latifolia & 13 & 0.3372 & 0.1157 & 0.1124 & $0.0455^{*}$ & $0.0279^{*}$ \\
\hline
\end{tabular}


Table 3

Results of joincount.test for BB statistic in radius of spatiall autocorrelations search $2250 \mathrm{~m}$; *distrbutions with positive spatial autocorrelation (see tab. 2).

\begin{tabular}{|c|c|c|c|}
\hline Species & Same colour statistic & Expectation & Variance \\
\hline Acorus calamus & 0.00000 & 0.03120 & 0.00217 \\
\hline Alisma plantago-aquatica* & 1.52000 & 1.12000 & 0.05150 \\
\hline Carex acutiformis & 0.39500 & 0.31200 & 0.01830 \\
\hline Carex elata & 0.49400 & 0.31200 & 0.01830 \\
\hline Carex gracilis* & 1.72000 & 1.41000 & 0.06000 \\
\hline Carex pseudocyperus & 0.25500 & 0.31200 & 0.01830 \\
\hline Carex vesicaria & 0.92300 & 0.65600 & 0.03410 \\
\hline Eleocharis palustris* & 1.49000 & 1.12000 & 0.05150 \\
\hline Elodea canadensis & 0.18400 & 0.09370 & 0.00617 \\
\hline Equisetum fluviatile* & 1.89200 & 1.41000 & 0.06000 \\
\hline Galium palustre & 1.44000 & 1.41000 & 0.06000 \\
\hline Glyceria fluitans & 8.31000 & 8.62000 & 0.09240 \\
\hline Glyceria maxima* & 0.68600 & 0.46900 & 0.02590 \\
\hline Hottonia palustris* & 0.24600 & 0.09370 & 0.00617 \\
\hline Iris pseudacorus & 0.57500 & 0.87500 & 0.04270 \\
\hline Lemna minor & 10.8900 & 10.9700 & 0.06890 \\
\hline Lemna trisulca & 2.35000 & 2.44000 & 0.08360 \\
\hline Oenanthe aquatica & 0.00000 & 0.09370 & 0.00617 \\
\hline Phalaris arundinacea & 2.55000 & 2.44000 & 0.08360 \\
\hline Phragmites australis & 0.70200 & 0.46900 & 0.02590 \\
\hline Poa palustris & 0.25900 & 0.31200 & 0.01830 \\
\hline Potamogeton natans & 1.15000 & 1.12000 & 0.05150 \\
\hline Rumex hydrolapathum* & 0.25100 & 0.09310 & 0.00617 \\
\hline Sium latifolium & 0.07420 & 0.03120 & 0.00217 \\
\hline Scutellaria galericulata & 0.20200 & 0.31200 & 0.01830 \\
\hline Sparganium emersum & 0.09170 & 0.09370 & 0.00617 \\
\hline Sparganium erectum* & 1.30000 & 0.87500 & 0.04270 \\
\hline Spirodela polyrhiza & 1.88000 & 2.06000 & 0.07630 \\
\hline Typha latifolia* & 2.93000 & 2.44000 & 0.08360 \\
\hline
\end{tabular}




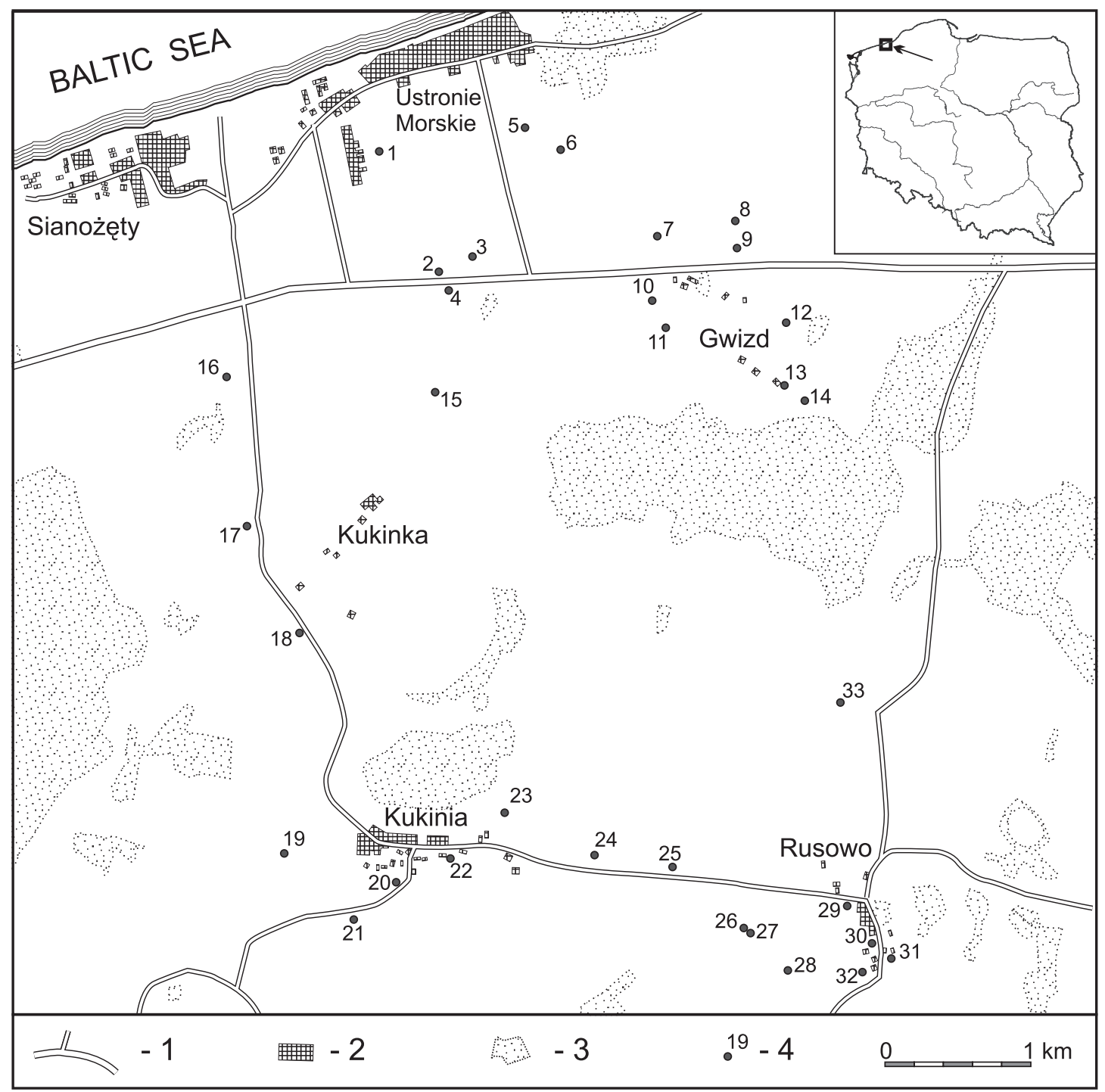

Fig. 1. Study area 1, roads; 2 , towns and villages; 3 , forests; 4 , localization and the number of midfield water body.

Our analysis of distribution of indicator plant species among 33 midfield water bodies was based on the identical assumption that the value of inter-site connection weights implies knowledge of the dispersal rate between sites. The choice of weights (e.g. Euclidean distance) represents assumptions about habitats, and so can be used as a statistical approach to testing the importance of those assumptions (e.g. inter-site dispersal) to species' presence/absence patterns. Comparisons of those weighting approaches among multiple sites should be useful in statistical evaluations of dispersal and its role in regulating community structure.
The absence of positive autocorrelation in distribution among the midfield ponds analysed was shown both by the species distributed among a low number of ponds (e.g. Acorus calamus, Elodea canadensis, Carex pseudocyperus, Sparganium emersum) and by some species present in many, or most, ponds (e.g. Glyceria fluitans, Lemna minor, L. trisulca, Spirodela polyrhiza). It may be assumed that the latter were the most successful in their dispersal among the available hydrogenic habitats in the area of study. Most species showing positive spatial autocorrelation in their distributions were present in 3-13 midfield ponds located at a search radius of $2250 \mathrm{~m}$. Based on conclusions pro- 


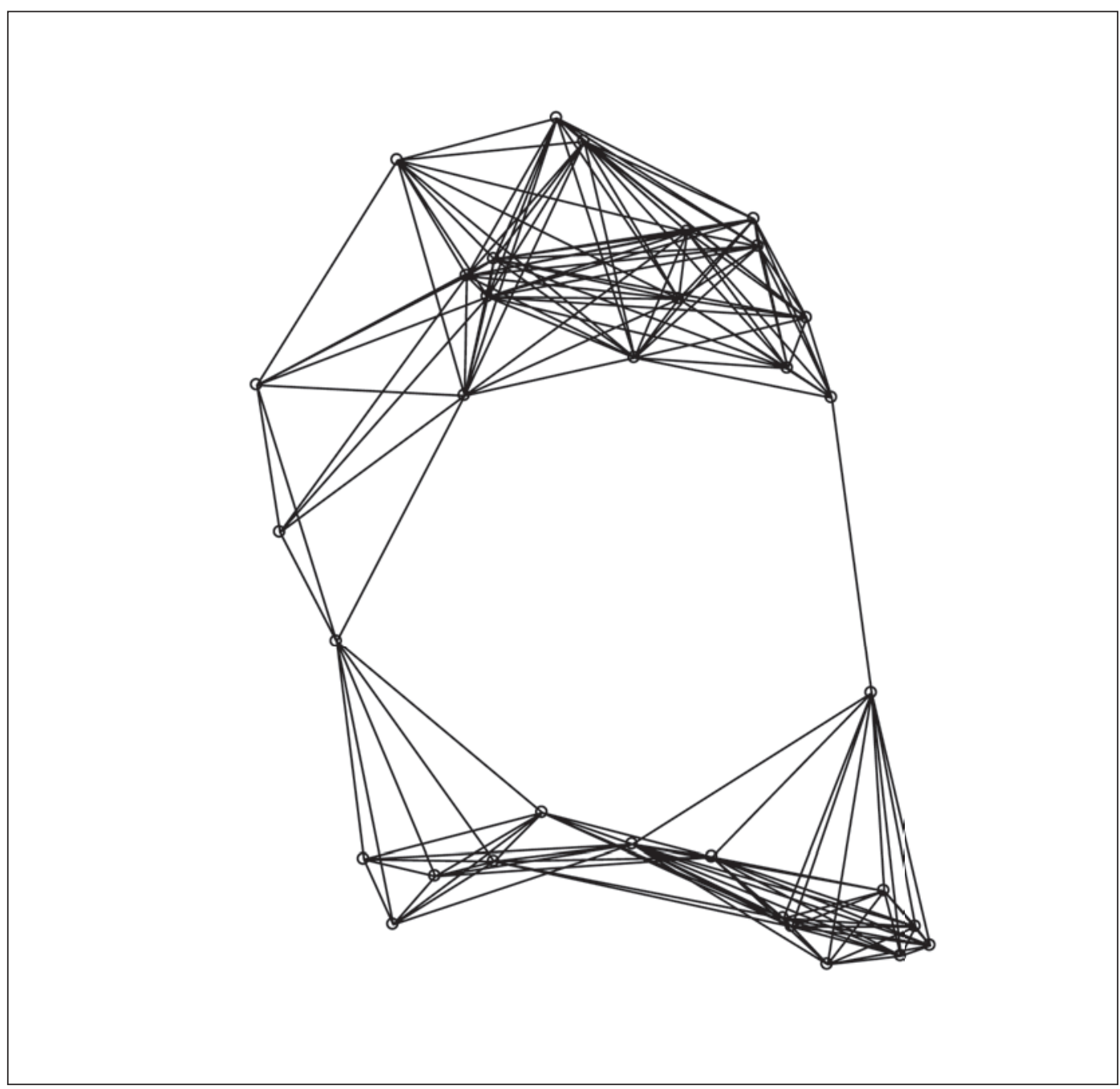

Fig. 2. A schematic diagram of nearest neighbour selection of individual midfield ponds within a radius of $2250 \mathrm{~m}$.

duced by ESDA, the spatial randomness hypothesis can thus be rejected in their case, which opens up an avenue for exploring spatial patterns. Further investigations of mechanisms causing this species distribution, e.g. hydroperiod, biotic interactions, dispersal possibilities (anemochory, epizoochory, endozoochory) are clearly necessary. It will be also interesting to compare results of analyses of species distributions among midfield ponds in various regions differing in the location and density of those water bodies. It will be perhaps possible to identify a group of species indicative of those habitats, the dispersal of which is limited regardless of area characteristics. Activities promoting the presence of such species (e.g. restoration of vanished water bodies, formation of new ones) should take into account the species' preferences with respect to appropriately shorter distances between the neighbouring habitats. This will make it possible to plan the conservation of midfield water bodies not only as refuges, but also as stepping stone habitats that facilitate migrations of wild species growing in an agricultural landscape, the presence of such species being conducive to restoring ecological balance in that landscape. 


\section{REFERENCES}

Boothby J., Swan M. J. S., Hull A. P., 1996. Biodiversity in dense pond landscapes: approaches and targets. [In:] The spatial dynamic of biodiversity. J. Simpson, A. P. Denis (eds), IALE (UK): 139-146.

Bosiacka B., Myśliwy M., 2004. The vegetation of midfield water bodies in western part of Słowiński Coastland. Przegląd Przyr. 15 (3-4): 31-61, (in Polish).

Bullock J. M., Moy I. L., Pywell R. F., Coulson S. J., Nolan A. M., Caswell H., 2002. Plant dispersal and colonization processes at local and landscape scales. [In:] Dispersal ecology. J.M. Bullock, R. E. Kenward, R. S. Hails (eds), Blackwell Publishing: 173-302.

Cliff A. D., Ord J. K., 1971. Evaluating the percentage points of a spatial autocorrelation coefficient. Geograph. Anal. 3: 51-62.

Cliff A. D., Ord J. K., 1981. Spatial Accesses: Models and Applications. Pion, London.

Earicson R., Harlin J., 1994. Geographic measurement and quantitative analysis. Macmillan College Publishing Company, New York: 1-104.

Greene D. H., Calogeropoulos C., 2002. Measuring and modeling seed dispersal of terrestrial plants. [In:] Dispersal ecology. J. M. Bullock, R. E. Kenward, R. S. Hails (eds), Blackwell Publishing: 3-23.

Hull A., 1997. The pond life project: a model for conservation and sustainability. [In:] British Pond Landscape, Proceedings from the UK conference of the Pond Life Project. J. Boothby (ed.), Pond Life Project, Liverpool: 101-109.

Kaźmierczak E., van der Maarel E., Noest V., 1995. Plant communities in kettle holes in central Poland: chance occurrence of species? J. Veg. Sci. 6: 863-874.

Kopczewska K., 2006. Econometrics and spatial statistic using R CRAN software. CeDeWu, Warszawa: 1-161, (in Polish).

Kucharski L., Samosiej L., 1990. Delimitation of the optimum network of midfield pools in order to preserve the resources of wild-growing species in agricultural landscape. Acta Univ. Lodz., Folia Bot. 10: 109-121 (in Polish).

Levine N., 1999. CrimeStat: A spatial statistics program for the analysis of crime incident locations (version 1.1). Washington: Ned Levine \& Associates, Annandale and the National Institute of Justice: 1-197.

Pieńkowski P., 2003. Analysis of distribution and changes in the occurrence of ponds in the NW area of Poland. Rozpr. Akad. Roln. w Szczecinie 222: 1-122, (in Polish).

Program R (version 2.6.0.), 2007. http: //www.r-project.org/ Copyright (C) The R Foundation for Statistical Computing.

Pullin S. A., 2002. Conservation biology. Cambridge University Press: 1-344.
Ratyńska H., 2002. Habitat islands as landscape components, typology trial and differentiation of vegetation. [In:] Habitat islands. Biodiversity and typology trial. J. Banaszak (ed.), Wyd. Akademii Bydgoskiej im. K. Wielkiego: 239-260 (in Polish).

Stevens P. H., Jenkins D. G., 2000. Analyzing species distributions among temporary ponds with a permutation test approach to the join-count statistic. Aquatic Ecology, 34: 91-99.

\section{Przestrzenna analiza rozmieszczenia gatunków roślin wśród małych zbiorników wodnych w krajobrazie rolniczym}

\section{Streszczenie}

Śródpolne oczka wodne ze względu na małe rozmiary $(0,02-1,0$ ha), wyraźnie zaznaczone granice oraz duży kontrast warunków wobec otaczającego je tła, zaliczane są do tzw. wysp środowiskowych. W krajobrazie rolniczym pełnią one wiele ważnych funkcji bio- i fizjocenotycznych. Ich skuteczna ochrona wymaga znajomości możliwości dyspersyjnych zasiedlających je organizmów, jednak bezpośrednie dane empiryczne znane są dla bardzo niewielu gatunków. O możliwościach rozprzestrzenienia się danego gatunku można jednak wnioskować pośrednio na podstawie jego rozmieszczenia. Celem pracy jest odpowiedź na pytanie czy istnieje przestrzenna autokorelacja w rozmieszczeniu gatunków roślin między śródpolnymi oczkami wodnymi, czy też rozmieszczenie to jest losowe?

Analizę rozkładu przestrzennego oczek wodnych wykonano w programie CrimeStat, zaś analizę autokorelacji przestrzennej w rozmieszczeniu 29 gatunków przeprowadzono w programie R CRAN, w komendzie joincount.test. Przeglądowa analiza danych przestrzennych (ESDA) z wykorzystaniem statystyk join-count wykazała istnienie pozytywnej autokorelacji przestrzennej w rozmieszczeniu dziesięciu gatunków hydrofitów i helofitów. Na podstawie wniosków z ESDA można w ich przypadku odrzucić hipotezę o przestrzennej losowości, co otwiera drogę do poszukiwania reżimów przestrzennych. Działania protegujące występowanie gatunków o ograniczonych możliwościach dyspersyjnych powinny uwzględniać ich wymogi co do odpowiednio mniejszych odległości między sąsiadującymi siedliskami. Pozwoli to planować ochronę śródpolnych oczek wodnych nie tylko jako ostoi, ale także jako siedlisk pomostowych, sprzyjających przemieszczaniu się gatunków dziko rosnących w krajobrazie rolniczym. 